\title{
Nd and Sr isotopic evidence for the origin of tektite material from DSDP site 612 off the New Jersey coast
}

\author{
O. Stecher, H. H. Ngo, D. A. Papanastassiou and G. J. Wasserburg \\ The Lunatic Asylum of the Charles Arms Laboratory, Division of Geological and Planetary Sciences, \\ California Institute of Technology, Pasadena, CA 91125 USA
}

(Received 8 September 1988; accepted in revised form 20 April 1989)

\begin{abstract}
Late Eocene tektite material from DSDP site 612 is composed of angular to spherical tektites and microtektites containing abundant vesicles and a few unmelted to partially melted mineral inclusions. The major element compositions of the 612-tektites are generally comparable to those of North American tektites, but the physical features suggest that the DSDP-612 tektites were formed by less severe shock melting. The ${ }^{87} \mathrm{Sr} /{ }^{86} \mathrm{Sr}$ and ${ }^{143} \mathrm{Nd} /{ }^{144} \mathrm{Nd}$ compositions of 612 -tektites: a) show much wider ranges than the tightly constrained group of North American tektites and microtektites, and b) are significantly different from those of other groups of tektites. The existence of large isotopic variations in tektites from DSDP site 612 requires that they were formed from a chemically and isotopically heterogeneous material in a regime that is distinctive from that of other groups of tektites. $\mathrm{T}_{\mathrm{CHUR}}^{\mathrm{Nd}}$ and $\mathrm{T}_{\mathrm{UR}_{\mathrm{R}}}^{\mathrm{S}}$ model ages of the 612 -tektites indicate that they were formed from a crustal source of late Precambrian mean age $(800-1000 \mathrm{Ma})$ which in middle Palaeozoic time $(\approx 400 \mathrm{Ma})$ was further enriched in $\mathrm{Rb} / \mathrm{Sr}$ during sedimentary processes. These source characteristics suggest that the impact which produced the 612-tektites occurred in rocks of the Appalachian orogeny or sediments derived from this orogenic belt. Potential source materials for both 612-tektites and North American tektites are present on the eastern and southeastern part of the North American continent and its adjacent shelf. The distinct isotopic differences between 612-tektites and North American tektites indicate that the two groups of tektites were either formed by the impact of more than one bolide in the same general area, or by a single impact event that sampled different layers.
\end{abstract}

\section{INTRODUCTION}

A NEW LOCALITY WITH late Eocene tektite material has recently been described from core 21 of DSDP site 612 on the continental shelf, off the New Jersey coast (Thein, 1987; Keller et al., 1987). This locality is a unique site where microtektites $(<1 \mathrm{~mm})$ are found together with macroscopic tektites $(>1 \mathrm{~cm})$, and where abundant shocked minerals and rock fragments of detrital origin are associated with tektite material (Thein, 1987; Keller et al., 1987; Glass, 1988; Bohor et al., 1988). Furthermore, the abundance of tektite material at site 612 is much greater than at any other late Eocene tektite locality (Glass, 1988). This, along with the abundance of shocked minerals, shocked rock fragments, and the high proportions of vesicles in some of the tektites, has been taken as evidence that DSDP site 612 is close to the impact site (Koeberl and Glass, 1988).

The tektite material and detrital grains at DSDP site 612 are located in an $8 \mathrm{~cm}$ thick layer of siliceous carbonate sediments deposited on an unconformity. Within this tektite horizon, reworked foraminifera species of the middle Eocene Globorotalia lehneri Zone have been found along with foraminifera species of the latest Eocene foraminifera zone, Globorotalia cerroazulensis (Keller et al., 1987; Thein, 1987). The absence of some middle to upper Eocene foraminifera and radiolaria species across the unconformity has led Thein (1987) and Poag and Low (1987) to suggest that the hiatus represents a stratigraphic gap of $\approx 6$ Ma. However, the 612-tektite layer has also been reported to be placed in the Globigerapsis semiinvoluta Zone (Miller and Hart, 1987), which is one of the foraminifera zones that, according to Keller et al. (1987) and Thein (1987), forms part of the stratigraphic gap at this locality.

Thus the age of the 612-tektite horizon is still in dispute, and, due to the re-worked nature of this tektite-bearing horizon, it may not be possible to determine accurately the time of the tektite fall by micropaleontological/stratigraphic methods. Keller et al. (1987) estimated an age of $35.9 \pm 0.4 \mathrm{Ma}$ for the tektite-bearing horizon at DSDP site 612 using the EoceneOligocene boundary age determination by Montanari et al. (1985) and estimated sediment accumulation rates for the upper Eocene. Age determinations of North American tektites have given values of $34.1 \pm 0.6 \mathrm{Ma}$ by K-Ar isotopic measurements (Zähringer, 1963) and $35.1 \pm 0.7 \mathrm{Ma}$ by fission track counting (Fleischer and Price, 1964; Storzer and Wagner, 1971, 1979; Storzer et al., 1973; Garlick et al., 1971) on macroscopic tektites, and 35.4 $\pm 0.6 \mathrm{Ma}$ by ${ }^{40} \mathrm{Ar} /{ }^{39} \mathrm{Ar}$ dating of microtektites from Barbados (Glass et al., 1986a). The overall agreement between the stratigraphic age of the tektite-bearing horizon at DSDP site 612 and the radiometric ages of the North American tektites from other localities caused Thein (1987) and Keller et al. (1987) to correlate the 612-tektites with tektites from the North American tektite strewnfield.

North American tektites from Texas and Georgia as well as microtektites from the Caribbean Sea, Barbados and Gulf of Mexico display linear trends in major element variation diagrams (Cuttitta et al., 1967; Donnelly and Chao, 1973; Glass and Zwart, 1979). Major element analyses of microtektites and tektite fragments from DSDP site 612 (D'Hondt et al., 1987; Koeberl and Glass, 1988) plot along the major element trends established for North American tektites but tend to plot toward the $\mathrm{SiO}_{2}$-poor end of these trends.

Crystal-bearing microspherules have been found in the same biostratigraphic zone, Globorotalia cerroazulensis, as the one where the North American microtektites have been found (Glass and John, 1974; Glass et al., 1985; Keller et al., 1987). The covariation trends of major elements for these crystal-bearing microspherules are clearly different from those of the microtektites. Multivariate statistical methods using major element compositions can easily separate the two types of impact generated spherules (D’Hondt et al., 1987).

The occurrence of North American tektites was for many years restricted to localities in Texas and Georgia (Barnes, 1940) 


\section{North American Tektite Strewnfield}

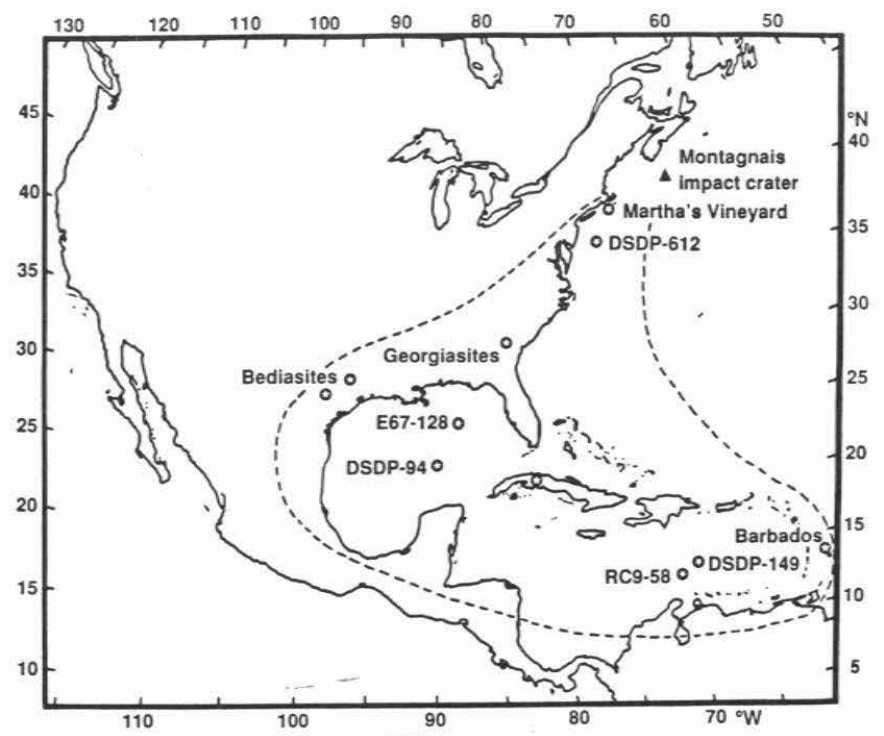

FIG. 1. Map showing the extent of the North American tektite strewnfield. Tektite localities and the location of the Montagnais impact crater are indicated.

although one tektite was found on Martha's Vineyard (Kaye et al., 1961) and another tektite has been reported to have been found in Cuba (Garlick et al., 1971). However, the discoveries of microtektites in deep sea drill cores (Donnelly and Chao, 1973; Glass et al., 1985) and on Barbados (Sanfilippo et al., 1985) expanded the North American tektite strewnfield to cover the Caribbean Sea and Gulf of Mexico. If the late Eocene tektite material from DSDP site 612 can be correlated with North American tektites, this would expand the strewnfield considerably to the north (Fig. 1).

The Sm-Nd and Rb-Sr study of tektites by Shaw and Wasserburg (1982) established that tektites from each of the known strewnfields have distinctive isotopic signatures with limited variations in ${ }^{143} \mathrm{Nd} /{ }^{144} \mathrm{Nd}$ and ${ }^{87} \mathrm{Sr} /{ }^{86} \mathrm{Sr}$ compositions. The values of ${ }^{143} \mathrm{Nd} /{ }^{144} \mathrm{Nd}$ are consistent with provenance of the tektites from continental materials of well defined mean crustal age. The variations in $\mathrm{Sr}$ isotopes are usually correlated with the degree of $\mathrm{Rb} / \mathrm{Sr}$ enrichment in the tektites. This geochemical behavior can be explained by selective enrichment of $\mathrm{Rb}$ in clay minerals formed during sedimentary processes, which generally preserve the relative proportions of the different rare earth elements (McCulloch and Wasserburg, 1978; McLennan et al., 1980; Taylor and McLennan, 1981). Shaw and Wasserburg (1982) concluded that the isotopic systematics of the tektites were consistent with formation of tektites by impact melting of continentally derived sediments. The isotopic composition of $\mathrm{Nd}$ thus reflects the average age of the continental crust from which the sediments were derived, and the correlation of ${ }^{87} \mathrm{Sr} /{ }^{86} \mathrm{Sr}$ with $\mathrm{Rb} /$ $\mathrm{Sr}$ permits an estimate of the sedimentation age.

Attempts to associate microtektites from deep sea drill cores with macroscopic tektites found on land have met some resistance (Baker, 1968; Chalmers et al., 1976; Berggren et al., 1985). A debate on the stratigraphic interpretation of different deep sea drill cores, along with a dispute over the occurrence of microtektite and microspherule layers in the late Eocene (Keller et al., 1983; Glass, 1984; Keller et al., 1984; Keller et al., 1987; D'Hondt et al., 1987; Glass and Burns, 1987; Keller and D'Hondt, 1988), has cast some doubt on the correlation of late Eocene microtektites with macroscopic North American tektites. These controversies and the advancement of microanalytical techniques (Papanastassiou and Wasserburg, 1981) prompted an isotopic study of late Eocene microtektites from Barbados (Ngo et al., 1985). Individual microtektites from Barbados were analyzed for $\mathrm{Nd}$ and $\mathrm{Sr}$ isotopic composition, and the results demonstrated that the Barbados microtektites have a clear isotopic affinity with macroscopic North American tektites.

The unique characteristics and mode of occurrence of the tektite material from DSDP site 612 and the generosity of G. Keller in providing us with appropriate samples caused us to initiate the present isotopic study in order to determine whether these tektites could be assigned to the North American strewnfield based on their isotopic compositions. We also present data for four macroscopic North American tektites, provided to us by Virgil Barnes. In this paper, the term North American tektites (NAT) refers to macroscopic tektites from Texas, Georgia, Martha's Vineyard and Cuba as well as late Eocene microtektites with similar geochemical characteristics as the macroscopic NAT. The 612-tektites are treated as a separate group of tektites, although it is the finding of this paper, that they and NAT originated from regions of similar chemical characteristics and mean ages.

\section{SAMPLE DESCRIPTION}

The 612-tektites were kindly supplied by G. Keller; similar tektites have been described by Keller et al. (1987) and D'Hondt et al. (1987). The samples consisted of 9 small tektites (range of largest dimension: 0.7 to $1.5 \mathrm{~mm}$ ) from DSDP 612 , core 21 , section $5,115-118 \mathrm{~cm}$; along with an unusually large tektite fragment (largest dimension: $1.4 \mathrm{~cm}$ ) from core 21 , section $5,114-115 \mathrm{~cm}$. The small tektites (Fig. 2a) consist of spherical to subspherical microtektites as well as angular tektite fragments. These tektites display varying degrees of calcite and marcasite coatings. Two of the tektites showed signs of devitrification. Most of the 612 -tektites have significant proportions of vesicles (up to $10 \%$ by volume). The large tektite fragment (Fig. 2b) had abundant and mostly elongated vesicles, one of which extended through its length. The large tektite fragment also contained abundant inclusions of lechatelierite and mineral grains that occasionally had a laminated appearance. Less abundant lechatelierite inclusions have also been recorded in the small tektites. The 612-tektites used in our study displayed no evidence of dendritic or angular voids similar to those found by Glass (1987) in glassy spherules from the 612-tektite horizon. Six small tektites, that displayed no evidence of devitrification, were selected for isotopic work. In addition, V. E. Barnes kindly supplied us with specimens of four macroscopic tektites from eastern Lee County, Texas.

\section{PREPARATION AND PROCEDURES}

The tektite samples were ultrasonically cleaned with high purity reagents by the following scheme: (1) $2 \mathrm{~N} \mathrm{HCl}$, for $8 \mathrm{~min}$; (2) rinsing with $\mathrm{H}_{2} \mathrm{O}$; (3) $7 \mathrm{~N} \mathrm{HNO}_{3}$, for 8 min; (4) rinsing with $\mathrm{H}_{2} \mathrm{O}$; (5) water extraction with acetone; and (6) drying under a heat lamp. These steps were necessary to ensure removal of surficial coatings. Two slices were cut $(0.9$ $\mathrm{cm}$ apart) from the large tektite fragment and each slice was individually cleaned. The complete removal of surficial deposits from all samples was checked using a microscope. Each tektite was then mounted in soluble thermoplastic cement, and a small area was polished and analyzed by energy dispersive X-ray spectrometry on a scanning electron microscope. Slice $612-\mathrm{Ll}$ was also analyzed by wavelength dispersive $\mathrm{X}$-ray spectrometry on an electron microprobe.

The samples were checked for homogeneity of the major elements and no chemical differences larger than the analytical uncertainties were detected. The major element compositions of the two slices (612-L1 
and 612-L2) from the large tektite fragment revealed no major chemical variations (Table 1). Chemical analyses of the surfaces and corresponding interior parts of individual microtektites revealed no evidence of leaching due to diagenetic or laboratory processes. No evidence of residual surficial coating was found.

Each tektite sample was recovered by dissolving the thermoplastic cement in acetone, and by further cleaning in acetone, methanol and water using an ultrasonic bath. Each sample was then individually dissolved in a $\mathrm{HF}-\mathrm{HClO}_{4}$ mixture; and the tracer addition and chemical separations followed previously described procedures ( $c f$., Papanastassiou et al., 1977). Yields for $\mathrm{Sr}$ and Nd were checked on each sample and found to be better than $95 \%$. Isotopic compositions and elemental concentrations were analyzed on the Lunatic I and III mass spectrometers on loads of 7 to $10 \mathrm{ng}$ for $\mathrm{Nd}$ and 25 to $300 \mathrm{ng}$ for Sr. Total procedural blanks were measured prior to and during this work and gave the following values: $\mathrm{Rb} 9 \mathrm{pg}, \mathrm{Sr} 43 \mathrm{pg}, \mathrm{Sm} 3 \mathrm{pg}$ and $\mathrm{Nd} 18 \mathrm{pg}$. Contributions from these blanks are negligible. CIT standard n-Nd- $\beta$ was measured 7 times during the course of this experimental work and gave a mean $\epsilon_{\mathrm{Nd}}$-value of $-14.67 \pm 0.32(2 \sigma)$. The given uncertainty is twice the standard deviation of the means of individual standard analyses.

The four macroscopic NAT from Texas were analyzed following the above procedures with the exception that all exterior surfaces of these tektites were removed prior to the analytical work. The interior of these samples were cleaned only in acetone and distilled water.

\section{RESULTS}

The 612-tektites analyzed in this study have major element compositions (Table 1) that are comparable to those of other 612-tektites (D'Hondt et al., 1987; Koeberl and Glass, 1988). Major element compositions of 612-tektites and NAT generally plot along the same linear trends in variation diagrams (Cuttitta et al., 1967; Donnelly and Chao, 1973; Glass and Zwart, 1979). However, the 612-tektites analyzed in this study plot toward more $\mathrm{SiO}_{2}$-poor compositions than NAT (Fig. 3) and are characterized by having higher $\mathrm{K}_{2} \mathrm{O}$ concentrations than NAT.

The macroscopic NAT and the microscopic tektites from Barbados, that have been analyzed for $\mathrm{Sm}-\mathrm{Nd}$ and $\mathrm{Rb}-\mathrm{Sr}$ (Shaw and Wasserburg, 1982; Ngo et al., 1985), are all more $\mathrm{SiO}_{2}$-rich than the 612-tektites analyzed here. In order to analyze NAT samples with major element compositions that are similar to the 612-tektites we obtained four bediasite samples from the
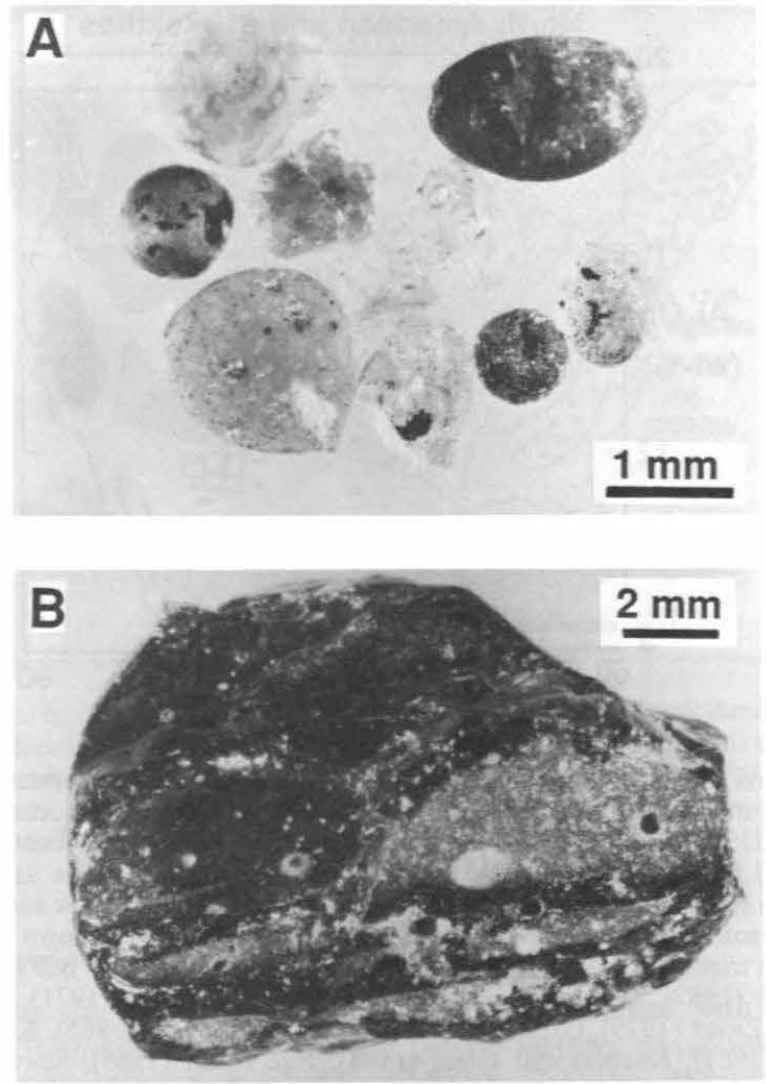

Fig. 2a. Photograph of the tektite material from DSDP site 612 prior to cleaning. Note the sulfide coating on the large egg-shaped tektite and on the small ball-shaped tektite on the left side of the photograph. A small spherical sulfide concretion is present on the lower right hand side of the photograph. Other tektites have minor calcite coatings and two of the tektites show evidence of devitrification. Fig. 2b. Photograph of the $1.4 \mathrm{~cm}$ large tektite fragment from DSDP site 612. Two slices, 612-L1 and 612-L2, used for chemical and isotopic determinations were cut from each end of this large tektite fragment.

TABLE 1. Major element compositions of 612 -tektites and bediasites in weight percent.

\begin{tabular}{|c|c|c|c|c|c|c|c|c|c|c|}
\hline & $\mathrm{SiO}_{2}$ & $\mathrm{TiO}_{2}$ & $\mathrm{Al}_{2} \mathrm{O}_{3}$ & $\mathrm{FeO}$ & $\mathrm{MgO}$ & $\mathrm{CaO}$ & $\mathrm{Na}_{2} \mathrm{O}$ & $\mathrm{K}_{2} \mathrm{O}$ & $\mathrm{P}_{2} \mathrm{O}_{5}$ & Total \\
\hline $612-1^{1}$ & 73.36 & 0.78 & 14.55 & 4.03 & 1.19 & 1.09 & 1.03 & 2.49 & -3 & 98.52 \\
\hline $612-2^{1}$ & 74.23 & 0.58 & 13.87 & 3.54 & 1.01 & 0.76 & 1.35 & 4.68 & -3 & 100.02 \\
\hline $612-9^{1}$ & 72.82 & 0.73 & 14.49 & 4.61 & 1.18 & 1.00 & 1.19 & 2.78 & -3 & 98.80 \\
\hline $612-3^{1}$ & 76.12 & 0.88 & 12.90 & 4.32 & 1.11 & 0.91 & 0.77 & 3.01 & -3 & 100.02 \\
\hline $612-6^{1}$ & 74.17 & 0.71 & 14.23 & 4.70 & 1.23 & 0.68 & 0.70 & 3.98 & -3 & 100.40 \\
\hline $612-10^{1}$ & 73.34 & 1.01 & 14.87 & 4.51 & 1.15 & 0.74 & 0.82 & 3.58 & $-{ }^{3}$ & 100.02 \\
\hline $612-\mathrm{Ll}^{1}$ & 73.85 & 0.80 & 14.64 & 4.61 & 1.36 & 0.61 & 0.58 & 3.52 & -3 & 99.97 \\
\hline $612-\mathrm{L} 2^{\prime}$ & 73.08 & 0.83 & 14.91 & 4.71 & 1.26 & 0.68 & 0.61 & 3.72 & $-{ }^{3}$ & 99.80 \\
\hline $612-\mathrm{Ll}^{2}$ & 72.61 & 0.83 & 14.38 & 4.65 & 1.17 & 0.66 & 0.53 & 3.49 & 0.05 & 98.42 \\
\hline $\mathrm{B} 12^{2}$ & 79.67 & 0.61 & 11.34 & 2.68 & 0.45 & 0.53 & 1.28 & 2.24 & 0.02 & 98.86 \\
\hline B7- $\mathrm{H}^{2}$ & 77.46 & 0.67 & 12.69 & 3.45 & 0.67 & 0.71 & 1.41 & 2.32 & 0.05 & 99.46 \\
\hline B $7-E^{2}$ & 74.34 & 0.92 & 15.61 & 4.58 & 0.61 & 0.42 & 1.04 & 1.58 & 0.02 & 99.15 \\
\hline B7-M ${ }^{2}$ & 73.71 & 0.67 & 11.21 & 4.95 & 2.82 & 2.05 & 1.22 & 2.19 & 0.06 & 98.98 \\
\hline
\end{tabular}

${ }^{1}$ Mean analytical values by energy dispersive X-ray analyses on a scanning electron microscope.

${ }^{2}$ Mean analytical values by wavelength dispersive X-ray analyses on an electron microprobe.

Below detection limit of 0.08 wt.\% for SEM analyses.

Samples 612-1, 612-2, 612-9 and 612-3 are spherical to subspherical microtektites from DSDP site 612. Samples 612-6 and 612-10 are angular tektite fragments from the same locality. 612-L1 and 612-L2 are slices cut off a $1.4 \mathrm{~cm}$ large tektite fragment from DSDP site 612. Samples B12, B7-H, B7-E and B7-M are bediasites from eastern Lee County, Texas. 


\section{North American and 612 tektites}

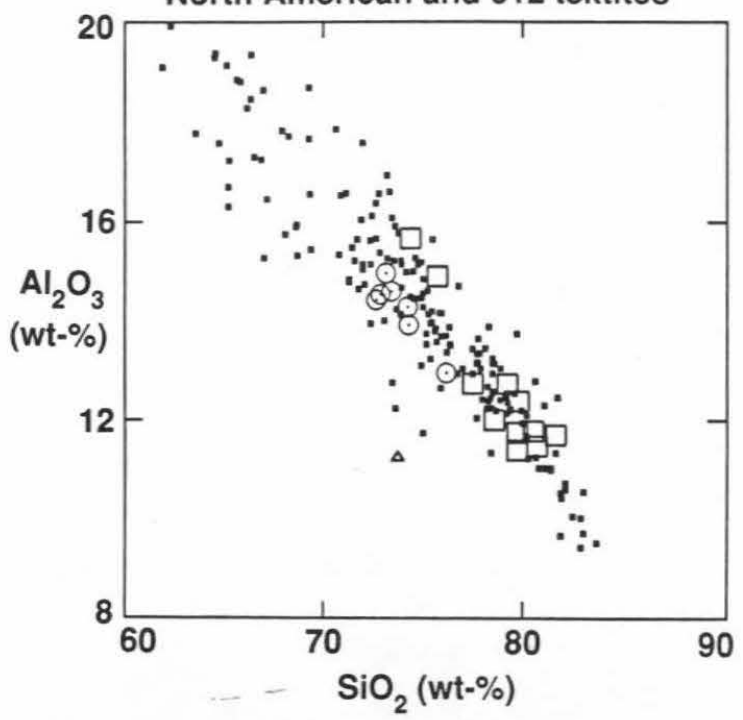

FIG. 3. $\mathrm{Al}_{2} \mathrm{O}_{3}-\mathrm{SiO}_{2}$ variations of macroscopic North American tektites, microtektites from Barbados, the Caribbean Sea, the Mexican Gulf and DSDP site 612. The North American tektites that have been analyzed for $\mathrm{Rb}-\mathrm{Sr}$ and $\mathrm{Sm}-\mathrm{Nd}$ isotopic composition are shown as large open squares; the 612-tektites that we have analyzed for $\mathrm{Rb}-\mathrm{Sr}$ and $\mathrm{Sm}$ $\mathrm{Nd}$ isotopes are shown as open circles. Sample B7-M is shown as an open triangle. Data from Barnes (1940), Cuttitta et al. (1967), D'Hondt et al. (1987), Donnelly and Chao (1973), Garlick et al. (1971), Glass and Zwart (1979), Glass and John (1974), Glass et al. (1985), Kaye et al. (1961), Koeberl and Glass (1988), Ngo et al. (1985), Shaw and Wasserburg (1982) and this study.

collection of V. E. Barnes. Based on the refractive indices of these samples, three bediasites were selected by V. E. Barnes to represent $\mathrm{SiO}_{2}$-poor NAT and one sample was selected to correspond to the more typical, high-silica NAT.

One of these low-silica bediasites (B7-M) turned out to have major element compositions and $\mathrm{Sr}$ and $\mathrm{Nd}$ isotopic compositions $\left(\epsilon_{\mathrm{Sr}}=+188, \epsilon_{\mathrm{Nd}}=-11.9\right)$, that are typical of Australasian tektites. The similarity of bediasite B7-M with Australasian tektites could be caused by a labelling problem, but V. E. Barnes'

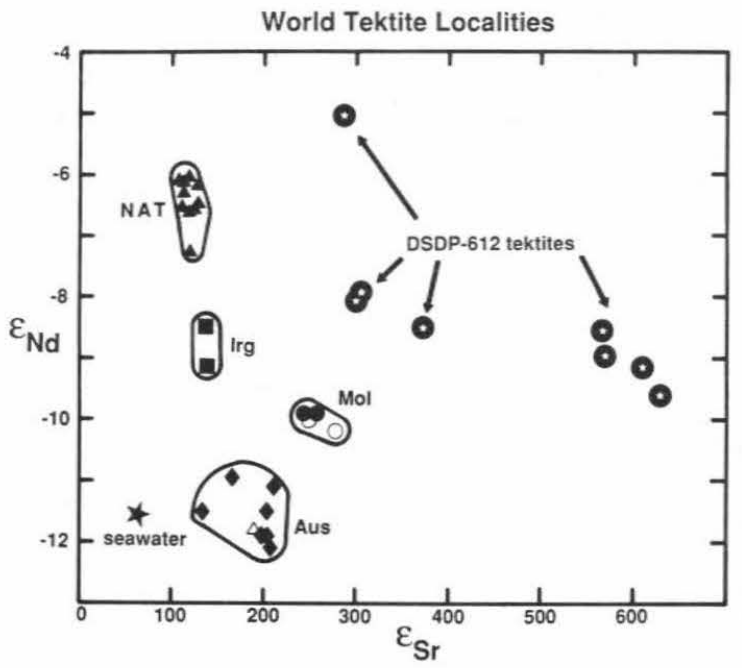

FIG. 4. $\epsilon_{\mathrm{Nd}} v s . \epsilon_{\mathrm{Sr}}$ for the tektites from DSDP site 612 are compared to tektites from well-known tektite strewnfields: North American tektites (NAT), silicic Irghizites (Irg), moldavites (Mol), Australasian tektites (Aus). The open circles in the moldavite field represent the OSMsands interpreted to be the source of the moldavites. Sample B7-M is shown as an open triangle in the Australasian tektite field. Data from this study, Shaw and Wasserburg (1982) and Ngo et al. (1985).

written notes on this sample (pers. comm., 1988) indicate that this sample was collected in eastern Lee County, Texas. If this sample is a genuine Texas tektite, this implies that the isotopic signature of NAT has a significantly larger range in $\epsilon_{\mathrm{Nd}}$ values than has previously been determined, or alternatively that the Australasian strewnfield extends to the North American continent. Because of the strong affinity of B7-M with Australasian tektites we do not include this sample in the discussion of NAT; see note added in proof. The three other bediasites cover nearly the whole range of $\mathrm{SiO}_{2}$-concentrations that has been reported for NAT, and only the most $\mathrm{SiO}_{2}$-poor sample (B7-E) has a $\mathrm{SiO}_{2}$-concentration ( $74.3 \mathrm{wt} . \%$ ) that is in the range of values for the 612-tektites analyzed here.

TABLE 2. Sm-Nd, $\mathrm{Rb}-\mathrm{Sr}$ isotopic results and parameters for isotopic evolution.

\begin{tabular}{|c|c|c|c|c|c|c|c|c|c|c|c|c|}
\hline & $612-1$ & $612-2$ & $612-9$ & $612-3$ & $612-10$ & $612-6$ & $612-\mathrm{L} 1$ & 612-L2 & B12 & B7-H & B7-E & B7-M \\
\hline Wt. ${ }^{1}$ & 2.00 & 0.65 & 1.30 & 0.37 & 0.67 & 0.77 & 27.67 & 18.89 & 49.00 & 52.22 & 33.82 & 24.76 \\
\hline $\mathrm{Rb}$ & 111.4 & 167.6 & 144.1 & 157.8 & 183.0 & 145.2 & 184.4 & 180.9 & 65.3 & 72.4 & 58.4 & 99.9 \\
\hline $\mathrm{Sr}$ & 155.7 & 106.7 & 168.8 & 150.0 & 92.7 & 72.9 & 85.0 & 83.7 & 154.2 & 159.2 & 117.4 & 135.9 \\
\hline Nd & 38.73 & 55.94 & 42.91 & 41.16 & 42.24 & 36.18 & 42.73 & 42.01 & 26.37 & 30.34 & 37.71 & 30.12 \\
\hline $\mathrm{Sm}$ & 7.55 & 8.97 & 8.41 & 8.13 & 8.56 & 7.07 & 8.43 & 8.33 & 5.19 & 6.01 & 7.46 & 5.80 \\
\hline $\mathrm{f}^{\mathrm{Rb} / \mathrm{Sr}}$ & 24.1 & 54.1 & 28.9 & 35.9 & 68.4 & 69.0 & 75.2 & 74.9 & 13.8 & 14.9 & 16.4 & 24.6 \\
\hline $\mathrm{f}^{\mathrm{Sm} / \mathrm{Nd}}$ & -0.400 & -0.507 & -0.398 & -0.392 & -0.377 & -0.399 & -0.394 & -0.390 & -0.395 & -0.391 & -0.392 & -0.408 \\
\hline \multirow[t]{2}{*}{$\epsilon_{\mathrm{Sr}}$} & 299.2 & 285.4 & 300.5 & 370.0 & 607.4 & 628.1 & 564.4 & 568.7 & 110.3 & 114.5 & 129.2 & 187.9 \\
\hline & \pm 0.6 & \pm 1.1 & \pm 0.6 & \pm 1.0 & \pm 2.1 & \pm 0.9 & \pm 0.8 & \pm 0.3 & \pm 0.3 & \pm 0.6 & \pm 0.5 & \pm 0.3 \\
\hline \multirow[t]{2}{*}{$\epsilon_{\mathrm{Nd}}$} & -8.1 & -5.1 & -8.0 & -8.5 & -9.3 & -9.7 & -8.6 & -8.9 & -6.3 & -7.1 & -6.1 & -11.9 \\
\hline & \pm 0.5 & \pm 0.4 & \pm 0.3 & \pm 0.6 & \pm 0.4 & \pm 0.5 & \pm 0.3 & \pm 0.4 & \pm 0.3 & \pm 0.4 & \pm 0.4 & \pm 0.5 \\
\hline $\mathrm{T}_{\mathrm{CHUR}}^{\mathrm{Nd}}$ & 801 & 403 & 797 & 855 & 980 & 963 & 863 & 905 & 637 & 717 & 622 & 1152 \\
\hline $\mathrm{T}_{\mathrm{UR}}^{\mathrm{Sr}}$ & 742 & 316 & 620 & 616 & 531 & 544 & 449 & 454 & 477 & 460 & 471 & 456 \\
\hline
\end{tabular}

${ }^{1}$ Weight in mg of microtektite or tektite fragment. Trace elements are given in ppm. Model ages are given in Ma. $\epsilon_{\mathrm{Sr}}, \mathrm{f}^{\mathrm{Rb} / \mathrm{Sr}}$ and $\mathrm{T}_{\mathrm{UR}}^{\mathrm{S}}$ are calculated relative to the present day bulk earth composition of ${ }^{87} \mathrm{Rb} /{ }^{86} \mathrm{Sr}=0.0827,{ }^{87} \mathrm{Sr} /{ }^{86} \mathrm{Sr}=0.7045 \mathrm{and}$ using $\lambda\left({ }^{87} \mathrm{Rb}\right)=$ $1.42 \times 10^{-11} \mathrm{a}^{-1}$.

$\epsilon_{\mathrm{Nd}}, \mathrm{f}^{\mathrm{Sm} / \mathrm{Nd}}$ and $\mathrm{T}_{\mathrm{CHUR}}^{\mathrm{Nd}}$ are calculated relative to a present day chondritic composition of ${ }^{147} \mathrm{Sm} /{ }^{144} \mathrm{Nd}=0.1967,{ }^{143} \mathrm{Nd} /{ }^{144} \mathrm{Nd}=0.511847$ and using $\lambda\left({ }^{147} \mathrm{Sm}\right)=6.54 \times 10^{-12} \mathrm{a}^{-1}$. 


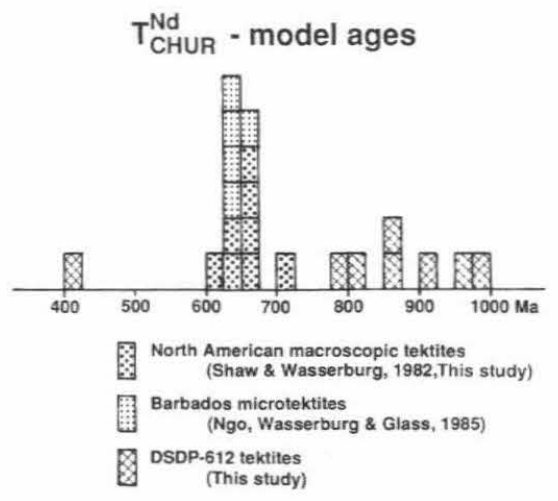

FIG. 5. Histogram of $T_{\text {CHUR }}^{\mathrm{Nd}}$ model ages of DSDP site 612 tektites compared to macroscopic North American tektites (Shaw and Wasserburg, 1982; this study) and microtektites from Barbados (Ngo et al., 1985).

Isotope dilution measurements on 612-tektites yield $\mathrm{Rb}, \mathrm{Sr}$, $\mathrm{Sm}$ and $\mathrm{Nd}$ concentrations (Table 2) that are comparable to NAT (Shaw and Wasserburg, 1982; Ngo et al., 1985; this study). The tektite spheres and fragments from DSDP site 612 have similar elemental abundances. However, the 612-tektite fragments have slightly lower $\mathrm{Sr}$ concentrations than the spherical to subspherical microtektites from the same locality as well as NAT from other localities.

The tektite material from DSDP site 612 has $\mathrm{Sr}$ and $\mathrm{Nd}$ isotopic compositions (Table 2, Fig. 4) that are markedly different from the NAT isotopic signature. The 612-tektites show larger variations in both $\mathrm{Sr}$ and $\mathrm{Nd}$ isotopic compositions than any other group of tektites. All are significantly more enriched in radiogenic strontium than NAT. The spherical to subspherical tektites from DSDP site 612 have $\epsilon_{\mathrm{Sr}}$-values from +285 to +370 , and the 612 -tektite fragments have the most radiogenic Sr-compositions $\left(\epsilon_{\mathrm{Sr}}=+564\right.$ to +628$)$ of any known tektites. The Nd isotopic compositions of 612-tektites also show deviations from the Nd compositions of NAT with the 612-tektite fragments having $\epsilon_{\mathrm{Nd}}$-values of -8.6 to -9.7 . Three of the spherical to subspherical 612-tektites have $\epsilon_{\mathrm{Nd}}$-values of -8.0 to -8.5 and one spherical microtektite (612-2) has a significantly higher $\epsilon_{\mathrm{Nd}}$-value of -5.1 than the other 612-tektites and NAT.

Bediasite samples B12, B7- $\mathrm{H}$ and $\mathrm{B} 7-\mathrm{E}$ have $\mathrm{Sr}$ and Nd isotopic compositions $\left(\epsilon_{\mathrm{Sr}}=+110\right.$ to $+129 ; \epsilon_{\mathrm{Nd}}=-6.1$ to -7.1$)$ that are indistinguishable from those of previously analyzed NAT (Shaw and Wasserburg, 1982; Ngo et al., 1985). The major element composition of the silica-poor bediasite, B7-E, extends the chemical range of NAT with $\mathrm{Rb}-\mathrm{Sr}$ and $\mathrm{Sm}-\mathrm{Nd}$ isotopic determinations to include $\mathrm{SiO}_{2}$ concentrations similar to the 612-tektites. Despite the major element similarities of bediasite B7-E and the 612-tektites, there are no similarities in $\epsilon_{\mathrm{Sr}}$ and $\epsilon_{\mathrm{Nd}}$.

\section{DISCUSSION}

The 612-tektites have major and trace element characteristics and a stratigraphic age that are sufficiently similar to those of NAT to suggest a genetic link between these two groups of tektites. However, the ${ }^{87} \mathrm{Sr}$ and ${ }^{143} \mathrm{Nd}$ isotopic compositions of 612 -tektites are significantly different and more varied than the narrow ranges of isotopic compositions determined for NAT.

\section{$\mathrm{T}_{\text {CHUR }}^{\mathrm{Nd}}$ - model ages}

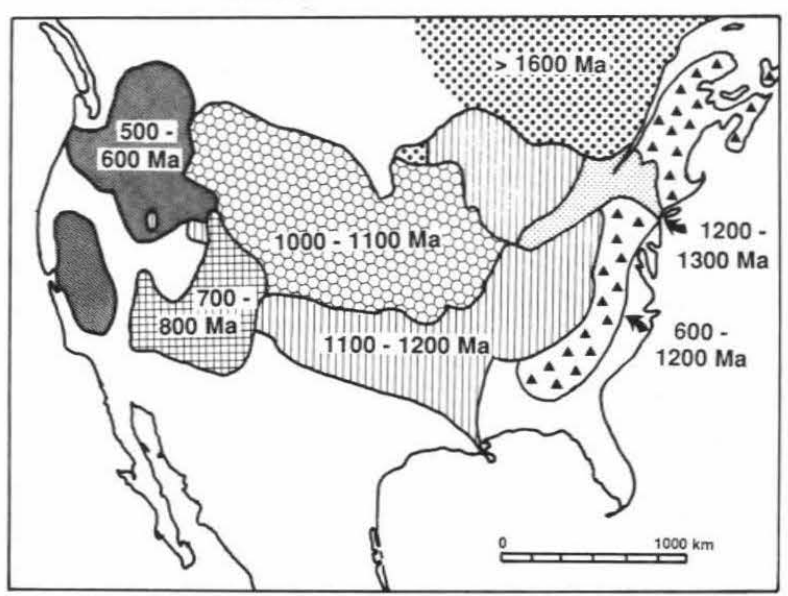

FIG. 6. T⿱N $\mathrm{T}_{\mathrm{CH}}^{\mathrm{H}}$ model ages of different areas of the North American continent. The diagram is based on ${ }^{143} \mathrm{Nd} /{ }^{144} \mathrm{Nd}$ determinations of the suspended load in selected North American rivers (Goldstein and Jacobsen, 1988). Determinations on Appalachian rocks have been included (Shaw and Wasserburg, 1984).

\section{Provenance of Tektite Source Material}

The silica-rich compositions of NAT combined with their LREE enrichment patterns are typical features of continental crust or sediments derived from continental areas. Oxygen isotopic determinations of NAT indicate that weathered or hydrothermally altered igneous rocks or immature continentally derived sediments are among the possible sources of NAT, whereas soils, shales and sandstones cannot be the source of NAT (Taylor and Epstein, 1969). The negative $\epsilon_{\mathrm{Nd}}$-values and positive $\epsilon_{\mathrm{Sr}}$-values of NAT indicate that the crustal material giving rise to NAT had a long-standing fractionation of $\mathrm{Sm} / \mathrm{Nd}$ and $\mathrm{Rb}$ / $\mathrm{Sr}$ relative to a bulk earth composition. The mean age of the enrichment event relative to a chondritic reservoir is given by $T_{C H U R}^{N d}$ model ages. NAT display a narrow range of $T_{C H U R}^{\mathrm{Nd}}$ model ages from 620 to $720 \mathrm{Ma}$ (Fig. 5). With the exception of microtektite 612-2, the 612-tektites have similar degrees of fractionation in $\mathrm{Sm} / \mathrm{Nd}$ which, combined with their less radiogenic $\epsilon_{\mathrm{Nd}}$-values, result in $T_{\mathrm{CHUR}}^{\mathrm{Nd}}$ model ages $(800-980 \mathrm{Ma})$ that are older than those of NAT. Microtektite 612-2 has Sr and Nd isotopic values and model ages that suggest it has an origin distinct from that of other 612-tektites and NAT. Sample 612-2 is most noteworthy in having a different $\mathrm{Sm} / \mathrm{Nd}$ enrichment factor $\left(f^{\mathrm{Sm} / \mathrm{Nd}}=-0.507\right)$ and younger model ages $\left(\mathrm{T}_{\mathrm{CHUR}}^{\mathrm{Nd}}=403\right.$ $\mathrm{Ma}, \mathrm{T}_{\mathrm{UR}}^{\mathrm{S}}=316 \mathrm{Ma}$ ) than other 612 -tektites or NAT. The young model ages for this sample indicate that the 612 source material has a component of late to middle Palaeozoic crustal addition.

The late Precambrian $\mathrm{T}_{\mathrm{CHUR}}^{\mathrm{Nd}}$ model ages of NAT exclude most of the Precambrian shield areas of the North American continent as potential source areas for NAT, as well as areas that are covered by sediments derived from these shield areas. Shaw and Wasserburg (1982) concluded that sediments derived from the eastern and southeastern margin of the Appalachian orogenic belt could have given rise to NAT by impact melting. Recent results give a more detailed picture of the age and $\mathrm{Rb}-\mathrm{Sr}$ and $\mathrm{Sm}-\mathrm{Nd}$ isotopic distribution of North American rock forma- 


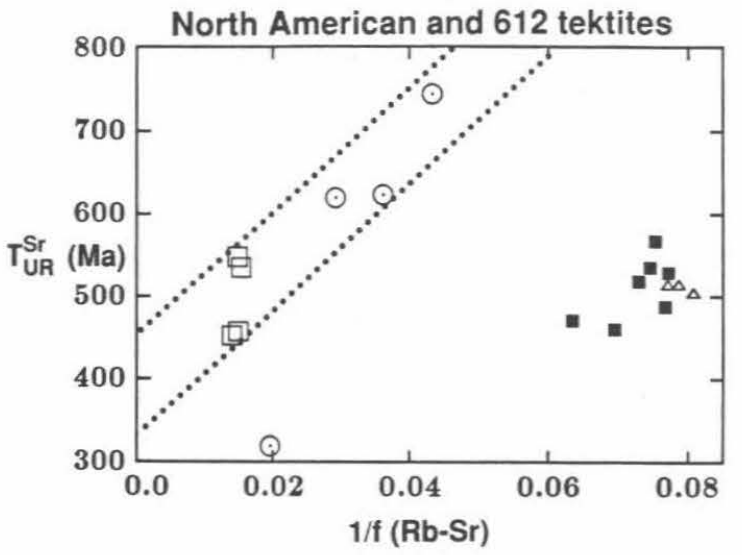

FIG. 7. Plot of $\mathrm{T}_{U \mathrm{R}}^{\mathrm{S} r}$ vs. $1 / \mathrm{f}^{\mathrm{Rb} / \mathrm{Sr}}$ for tektites from DSDP site 612 , macroscopic North American tektites and microtektites from Barbados. Open square symbols indicate tektite fragments from DSDP site 612, open circles are spherical to subspherical tektites from DSDP site 612. The filled squares represent macroscopic North American tektites, and the open triangles indicate microtektites from Barbados. The 612-tektites form a linear trend in this diagram, and the intercept of this trend with the $\mathrm{T}_{\mathrm{UR}}^{\mathrm{Sr}}$ axis gives the time of the last significant $\mathrm{Rb} / \mathrm{Sr}$ enrichment. The enrichment of $\mathrm{Rb} / \mathrm{Sr}$ is interpreted to be caused by sedimentary processes. Data from Shaw and Wasserburg (1982), Ngo et al. (1985) and this study.

tions (Goldstein and Jacobsen, 1988; Bennett and DePaolo, 1987). Figure 6 shows the distribution of $T_{C H U R}^{N d}$ model ages inferred from isotopic determinations of suspended load in North American rivers (Goldstein and Jacobsen, 1988) and a few Appalachian rocks (Shaw and Wasserburg, 1984). Based on these new data it is apparent that the eastern part of the North American continent, and areas covered by sediments derived from the eastern part of the continent, are possible source areas of NAT. Alternate sources from the western part of the North American continent would also be consistent with the $T_{\text {CHUR }}^{N d}$ model ages.

With the exception of microtektite 612-2, the 612-tektites have $\mathrm{T}_{\mathrm{CHUR}}^{\mathrm{Nd}}$ model ages $(800-980 \mathrm{Ma})$ that are older than NAT, but due to the scarcity of rocks with late Precambrian $\mathrm{T}_{\mathrm{CHUR}}^{\mathrm{Nd}}$ model ages on the North American continent, the source material of the 612-tektites is also constrained to the eastern North American continent with its adjacent continental shelf or alternatively to the western part of the North American continent.

\section{Later $\mathrm{Rb} / \mathrm{Sr}$ Enrichment}

Model ages of NAT calculated from the isotopic composition of $\mathrm{Sr}$ and the enrichment of $\mathrm{Rb} / \mathrm{Sr}$ relative to a bulk earth composition $\left(\mathrm{T}_{\mathrm{UR}}^{\mathrm{S} r}=460-570 \mathrm{Ma}\right)$ are significantly lower than the $T_{\text {CHUR }}^{N d}$ model ages (620-720 Ma) determined on the same samples. These differences between model ages indicate an additional increase in $\mathrm{Rb} / \mathrm{Sr}$ ratios for the source material for NAT, at a time after the initial $\mathrm{Rb} / \mathrm{Sr}$ enrichment associated with the formation of the crust. The uniformity of $\mathrm{Rb} / \mathrm{Sr}$ enrichment and the limited range in $\mathrm{T}_{U R}^{\mathrm{S} r}$ model ages of NAT prevented Shaw and Wasserburg (1982) from extracting information about the age of this later enrichment event.

The 612-tektites have $T_{U R}^{\mathrm{S} r}$ model ages (300, 450-740 Ma) that are significantly lower than their $\mathrm{T}_{\mathrm{CHUR}}^{\mathrm{Nd}}$ model ages (400,
800-980 Ma) and thus require an increase in $\mathrm{Rb} / \mathrm{Sr}$ of the 612 tektite source material after the crust forming event indicated by the $\mathrm{T}_{\mathrm{CHUR}}^{\mathrm{Nd}}$ model ages. In contrast to NAT, the 612-tektites display a significant range in $\mathrm{Rb} / \mathrm{Sr}$ enrichment values as well as in $\mathrm{T}_{\mathrm{UR}}^{\mathrm{Sr}}$ model ages, which allow an age to be inferred for this later $\mathrm{Rb} / \mathrm{Sr}$-enrichment. Shaw and Wasserburg (1982) described the ${ }^{87} \mathrm{Rb} /{ }^{86} \mathrm{Sr}-{ }^{87} \mathrm{Sr} /{ }^{86} \mathrm{Sr}$ and model age systematics of multiple stage $\mathrm{Rb} / \mathrm{Sr}$ evolution. An initial $\mathrm{Rb} / \mathrm{Sr}$ enrichment event (i.e., formation of the crust) can be assumed to produce rocks with similar ${ }^{87} \mathrm{Sr} /{ }^{86} \mathrm{Sr}$ values and a range of $\mathrm{Rb} / \mathrm{Sr}$ values. If this initial enrichment event is followed by an additional $\mathrm{Rb} / \mathrm{Sr}$ enrichment event (i.e., sedimentary processes or metamorphism) then the $\mathrm{T}_{\mathrm{UR}}^{\mathrm{S}} \mathrm{s}$ model ages for these rocks will be intermediate between the ages of the two enrichment events. With increasing degree of later $\mathrm{Rb} / \mathrm{Sr}$ enrichment the effect of the initial $\mathrm{Rb} / \mathrm{Sr}$ enrichment event becomes less significant and this causes the calculated $\mathrm{T}_{\mathrm{UR}}^{\mathrm{S}} \mathrm{m}$ model ages to approach the age of the last, major $\mathrm{Rb} / \mathrm{Sr}$ enrichment. This relationship can be portrayed in a diagram of $\mathrm{T}_{\mathrm{UR}}^{\mathrm{Sr}}$ model ages $v s .1 / \mathrm{f}^{\mathrm{Rb} / \mathrm{Sr}}$ (where $\mathrm{f}^{\mathrm{Rb} / \mathrm{Sr}}$ is the enrichment factor of $\mathrm{Rb} / \mathrm{Sr}$ relative to a bulk earth composition). The data points cover a wedge-shaped area that points towards the age of the last $\mathrm{Rb} / \mathrm{Sr}$ enrichment event. This method also applies to cases where multiple $\mathrm{Rb} / \mathrm{Sr}$ enrichment events have contributed to the $\mathrm{Rb} / \mathrm{Sr}$ ratio and ${ }^{87} \mathrm{Sr} /{ }^{86} \mathrm{Sr}$ composition of a rock, but the usefulness of the method depends on the dominance of the most recent $\mathrm{Rb} / \mathrm{Sr}$ enrichment.

The validity of this inferred age hinges on whether the $\mathrm{Rb} /$ $\mathrm{Sr}$ enrichment processes involved influx of strontium with an isotopic composition that was significantly different from that of the source material. The geochemical behavior of $\mathrm{Sr}$ during formation of clastic and pelitic sediments (Dasch, 1969), which are the sediment types that have chemical characteristics similar to the 612-tektites, suggests that uptake of isotopically different $\mathrm{Sr}$ is of minor importance.

The data points of the 612-tektites (with the exception of sample 612-2) display a linear array in a $T_{U R}^{\mathrm{S} r} v s .1 / \mathrm{f}^{\mathrm{Rb} / \mathrm{Sr}}$ diagram (Fig. 7). The relatively narrow width of this linear array suggests that the parental crustal material giving rise to the 612-tektites had a moderate range of $\mathrm{Rb} / \mathrm{Sr}$ ratios. Projection of the linear array of Fig. 7 onto the $T_{U R}^{S \delta}$ axis gives an intercept age of $\approx 400$ $\mathrm{Ma}$ for the late $\mathrm{Rb} / \mathrm{Sr}$ enrichment event.

\section{Geological Material at Impact Site}

$\mathrm{T}_{\mathrm{CHUR}}^{\mathrm{Nd}}$ and $\mathrm{T}_{\mathrm{UR}}^{\mathrm{s}} \mathrm{m}$ model ages of 612-tektites and NAT suggest that the source material of both types of tektites is derived from the eastern or southeastern part of the North American continent. The overall geochemical characteristics of the 612 -tektites are in accordance with a sedimentary origin for their source material, but the enrichment age inferred from Fig. 7 is significantly older than sediments found along the eastern North American continent or on the adjacent shelf(Olsson et al., 1988; Gohn, 1988). The middle Palaeozoic age of the Rb/Sr enrichment event suggests that sediments produced during or even incorporated in the Appalachian orogeny are a better choice for the source rocks of the 612-tektites, than the young sediments found along the eastern and southeastern part of the North American continent or the adjacent shelf.

The processes that deposited the sediments along the eastern and southeastern part of the North American continent and the adjacent shelf are too recent to account for the $\mathrm{T}_{\mathrm{UR}}^{\mathrm{S}_{\mathrm{R}}}-\mathrm{Rb} / \mathrm{Sr}$ re- 
lationship in Fig. 7. However, these young sediments could have preserved evidence for older model ages if the sediments of the impact area were formed by rapid denudation of Appalachian metasediments, followed by transport of the sediments without significant chemical alteration.

The small differences in $\mathrm{T}_{\mathrm{UR}}^{\mathrm{s}} \mathrm{r}$ and $\mathrm{T}_{\mathrm{CHUR}}^{\mathrm{Nd}}$ model ages for NAT suggest that the source material of these tektites has suffered less $\mathrm{Rb} / \mathrm{Sr}$ enrichment during the later event than the source material of the 612-tektites. However, the combination of $\mathrm{T}_{U \mathrm{R}}^{\mathrm{S}}$ model ages with $1 / \mathrm{f}^{\mathrm{Rb} / \mathrm{Sr}}$ values (Fig. 7) clearly demonstrates that the source material for NAT has a more uniform isotopic composition and has undergone a different evolution than the source material for the 612-tektites. This difference in composition between the two types of source materials cannot be interpreted as due to different degrees of $\mathrm{Rb} / \mathrm{Sr}$ enrichment during sedimentary processes, but the differences can be ascribed to different provenances of the sediments that constitute the two source materials. This explanation is also supported by the differences in $\mathrm{T}_{\text {CHUR }}^{\mathrm{Nd}}$ model ages between NAT and the 612-tektites.

\section{Impact Processes}

The $\mathrm{T}_{\mathrm{CHUR}}^{\mathrm{Nd}}$ model ages of 612 -tektites indicate that the source material of the 612-tektites had a higher proportion of an older crustal component than the source material of NAT. The $\mathrm{T}_{U \mathrm{UR}}^{\mathrm{Sr}}-$ $\mathrm{f}(\mathrm{Rb} / \mathrm{Sr})$ relationships of the two groups of tektites also indicate that the source materials for the two tektite groups are different. Despite these differences, the potential source materials for both 612-tektites and NAT are restricted to the same geographical area. This geographical area is the eastern and southeastern part of the North American continent and the adjacent continental shelf.

The differences in model ages and isotopic compositions for the 612-tektites and NAT can reflect either (1) the impact of more than one bolide in the same general area, or (2) can reflect a single impact event that sampled different layers of a chemically and isotopically inhomogeneous site.

The impact of more than one bolide in the same general area at geologically similar times cannot be ruled out based on the present evidence. Break-up of smaller meteoritic bodies due to their entrance into the Earth's atmosphere is a commonly recorded phenomenon ( $c f$., Krinov, 1966). Theoretical calculations (Melosh, 1981) indicate that break-up of impacting bodies due to their encounter with the Earth's atmosphere is unlikely for bolides of the dimensions needed to form the extensive amounts of tektite material associated with the strewnfield of NAT (Baldwin, 1981; Glass, 1988). However, the Steinheim crater (diameter $3.4 \mathrm{~km}$ ) and Ries crater (diameter $25 \mathrm{~km}$ ) of Southern Germany are located within $50 \mathrm{~km}$ of each other and they are believed to have been formed at geologically similar times (Reiff, 1977). If a single impact event has generated both 612-tektites and NAT then the elemental and isotopic differences between the two types of tektites reflect the original elemental and isotopic diversity of rocks from the impact site as well as the degree to which the ejecta blanket has been homogenized.

The relationship between the Ries crater and moldavites has been used to give valuable information about impact processes and the conclusions may apply to the impact processes giving rise to 612-tektites and NAT. The Ries impact is interpreted (Pohl et al., 1977) to have excavated $\approx 600 \mathrm{~m}$ of various sedi- mentary rock types (sandstones, limestones, marls, shales) and $\approx 1500 \mathrm{~m}$ of crystalline basement rocks. Only a $20-50 \mathrm{~m}$ thick Tertiary horizon (Upper Freshwater Molasse, OSM) at the very top of this stratigraphic column has chemical abundances and isotopic compositions that roughly correspond to those of the moldavites (Graup et al., 1981; Horn et al., 1985; von Engelhardt et al., 1987). The implication of this match between OSM sands and moldavites is that tektites of a strewnfield may exclusively be formed from a thin, surficial deposit without incorporating material from deeper levels at the impact site (Shaw and Wasserburg, 1982). High-velocity jets of surficial target material are often produced by large impacts; and oblique impacts are likely to produce directional jets (Kieffer, 1977).

NAT show a range of $\epsilon_{\mathrm{Sr}}$ and $\epsilon_{\mathrm{Nd}}$ values that is similar to the ranges determined for moldavites. The narrow and similar ranges of isotopic compositions for these two types of tektites may suggest that NAT, like the moldavites, have been formed from a thin and fairly homogeneous surficial deposit. The occurrence of unmelted and partially melted mineral inclusions along with irregular inclusions of lechatelierite in the 612-tektites (Thein, 1987; Glass et al., 1986b) would indicate that the source materials of these tektites have undergone less severe shock-induced melting compared to NAT. If this indication is correct then the large variations of $\epsilon_{\mathrm{Sr}}$ and $\epsilon_{\mathrm{Nd}}$ values as well as the dispersion of $T_{\mathrm{CHUR}}^{\mathrm{Nd}}$ model ages for the 612-tektites show that the source material of the 612-tektites was significantly more heterogeneous than the source material of NAT.

The occurrence of unmelted and partially melted mineral inclusions in the 612-tektites along with the high proportions of vesicles are some of the characteristics associated with impact melts found in the vicinity of impact craters (von Engelhardt et al., 1987). Impact melts associated with the Ries impact crater have mainly sampled the lower part of the stratigraphic sequence that was present at the impact site (Pohl et al., 1977). By analogy with this interpretation of the Ries crater impact melts, it may be inferred that the source material of the 612-tektites has been derived from a deeper stratigraphic level of the impact site than the source material of NAT.

Comparison of 612-tektites and NAT with moldavites and impact glasses from the vicinity of the Ries crater seems to indicate that NAT have been generated from a surficial deposit by high-velocity jets in the initial stages of the impact event. The 612-tektites are more likely to represent melts generated from a lower level of the stratigraphic column and they are thus from a slightly "later" stage of the impact explosion. Whether this comparison of 612-tektites and NAT with the Ries crater and moldavites is appropriate cannot be established at present. Obvious differences between the two impact events exist (i.e., the size of the strewnfields). Until an impact crater for the 612tektites and NAT has been positively identified, the correlations given must be considered tentative.

\section{Possible Source Craters}

A compilation of ages and sizes of terrestrial impact craters (Grieve, 1987) lists four impact craters (Mistastin, Wanapitei, Logoisk and Popigai) with fairly precise age determinations that, based on age, could be considered the source craters of NAT.

Mistastin is a $28 \mathrm{~km}$ wide impact crater on the crystalline basement near the border between Labrador and Quebec on the Precambrian shield of North America (Taylor and Dence, 1969). 
The age of this impact event has been determined to be $38 \pm$ $4 \mathrm{Ma}$ (Mak et al., 1976). The age, size and distance from the North American tektite strewnfield makes the Mistastin impact a potential source for NAT, but the pre-Grenvillian age of the crystalline basement at the impact site probably excludes this impact crater as a possible source of NAT.

The $8.5 \mathrm{~km}$ wide Wanapitei impact crater from the Sudbury area of the Canadian Precambrian shield was considered as a potential source for NAT. However, the $\mathrm{Sr}$ and $\mathrm{Nd}$ isotopic values of Wanapitei glasses $\left(\epsilon_{\mathrm{Sr}}=+960, \epsilon_{\mathrm{Nd}}=-31.4\right)$ and their $\mathrm{T}_{\mathrm{CHUR}}^{\mathrm{Nd}}$ model ages $(2.66 \mathrm{Ga})$ exclude this crater as a potential source (Ngo et al. 1985).

The $20 \mathrm{~km}$ wide Logoisk impact crater in the Byelorussian republic of the USSR has an age of $40 \pm 5 \mathrm{Ma}$ (Grieve, 1987). The impact crater is carved out of sedimentary rocks, and a potential source terrain of Late Proterozoic age is present in the vicinity of the impact crater. This allows for the possibility that rocks from the Logoisk impact crater have $\mathrm{Rb}-\mathrm{Sr}$ and $\mathrm{Sm}-\mathrm{Nd}$ isotopic signatures similar to those of NAT. However, the size of the crater combined with its distance from the North American strewnfield probably excludes this crater as a source of NAT.

The $100 \mathrm{~km}$ wide Popigai impact structure from the western part of northern Siberia has been suggested as a possible source for NAT (Dietz, 1977). Storzer and Wagner (1979) excluded this possibility based on a fission track age determination of $30.5 \pm 1.2 \mathrm{Ma}$. Recent ${ }^{40} \mathrm{Ar} /{ }^{39} \mathrm{Ar}$ determinations of glass samples from the Popigai impact crater give an age of $36 \mathrm{Ma}$ that is indistinguishable from the age of NAT (Bottomley and York, 1989). Shaw and Wasserburg (1982) excluded the Popigai structure as a potential source on the assumption that it is located on the Archaean Anabar shield. However, the impact structure has penetrated Mesozoic, Palaeozoic and Late Proterozoic sediments as well as basement rocks of the Archaean Anabar shield (Masaitis et al., 1980). Some of these sediments may have model ages that are similar to those of NAT, but the proximity of the Anabar shield may indicate that the $\mathrm{T}_{\mathrm{CHUR}}^{\mathrm{Nd}}$ model ages of these sediments are too old to be the source of NAT. Rb-Sr and SmNd determinations on an impact glass sample from Popigai give model ages $\left(\mathrm{T}_{\mathrm{CH} U R}^{\mathrm{Nd}}=2.00 \mathrm{Ga} ; \mathrm{T}_{\mathrm{UR}}^{\mathrm{Sr}}=1.82 \mathrm{Ga}\right)$ that indicate no genetic relationship with NAT (Stecher et al., 1989).

A recently discovered underwater impact crater, the Montagnais structure, $200 \mathrm{~km}$ southeast of Nova Scotia (Jansa and Pe-Piper, 1987), has been suggested as the source of NAT and 612-tektites (Glass, 1988). ${ }^{40} \mathrm{Ar} /{ }^{39} \mathrm{Ar}$ age determinations on samples from the Montagnais crater give an age of $51.5 \pm 0.8 \mathrm{Ma}$ (Bottomley and York, 1988), that is different from the age of NAT. Rb-Sr and Sm-Nd determinations on samples from the Montagnais crater give isotopic compositions and model ages that exclude a genetic relationship between the Montagnais impact crater and NAT or 612-tektites (Stecher et al., 1989).

\section{CONCLUSIONS}

Tektites from each of the known strewnfields have distinctive isotopic compositions with narrow ranges of $\epsilon_{\mathrm{Sr}}$ and $\epsilon_{\mathrm{Nd}}$ values. The 612-tektites have $\mathrm{Rb}-\mathrm{Sr}$ and $\mathrm{Sm}-\mathrm{Nd}$ isotopic compositions that deviate widely from those of NAT and reveal no affinity to any other group of tektites. The 612-tektites show a very large range in $\epsilon_{\mathrm{Sr}}$ values $(+285$ to +628$)$ and a less pronounced range in $\epsilon_{\mathrm{Nd}}$ values $(-5.1$ to -9.7$)$. These differences in isotopic values are significantly larger than for any other group of tektites, and the high $\epsilon_{\mathrm{Sr}}$ values exceed those of any other tektites.

612 -tektites and NAT have $\epsilon_{\mathrm{Sr}}$ and $\epsilon_{\mathrm{Nd}}$ values that are markedly different, but their model ages suggest that the source sediments for these two groups of tektites are from the same geographical area. The differences can thus be caused by (1) the impact of two (or more) bolides in the same general geographical area and at similar times, or (2) could be the result of a single impact event, that sampled different layers at the impact site. In any event the ejection process for the 612-tektites must be distinctive and the tektite formation must take place in a shock regime in which homogenization does not take place. This is likely to be a zone in which the target material was not totally melted.

The $T_{C H U R}^{N d}$ and $T_{U R}^{S r}$ model ages of 612-tektites and NAT suggest that the source materials of both of these tektites have been derived from the eastern or southeastern part of the North American continent. Sediments involved in the Appalachian orogeny are the likely sources for 612-tektites, and if these sediments later were redeposited without significant $\mathrm{Rb} / \mathrm{Sr}$ enrichment, then the impact site can be located within the Appalachian orogenic belt or the areas covered by sediments derived from the Appalachian orogenic belt.

Acknowledgments - We are indebted to the work of G. Keller and her willingness to provide us with well documented samples for this study. We thank V. E. Barnes for the samples of bediasites. Meticulous and diligent sample preparation by L. M. Hedges is acknowledged as is expert assistance by J. T. Armstrong and J. Sheng with the SEM and microprobe analyses. This work was supported by NASA, under grant NAG 9-43. Division contribution No. 4679 (638).

\section{Editorial handling: C. J. Allègre and J. T. Wasson.}

Note added in proof:

After the revision of this manuscript, Richard Bottomley, Geophysical Laboratory, University of Toronto, has analyzed the ${ }^{40} \mathrm{Ar} /{ }^{39} \mathrm{Ar}$ age of a fragment of tektite B7-M. The high temperature Ar release fractions accounts for $85 \%$ of the argon released and gives an ${ }^{40} \mathrm{Ar} /{ }^{39} \mathrm{Ar}$ age of $0.84 \pm 0.54 \mathrm{Ma}$. The age calculated from the total Ar released is 1.03 $\pm 0.17 \mathrm{Ma}$. These ages are in agreement with the fission track ages (0.6$0.8 \mathrm{Ma}$ ) of Australasian tektites. We conclude that the ${ }^{40} \mathrm{Ar} /{ }^{39} \mathrm{Ar}$ and the $\mathrm{Rb}-\mathrm{Sr}$ and the $\mathrm{Sm}-\mathrm{Nd}$ systematics are consistent with B7-M being an Australasian tektite, and that the $\mathrm{Rb}-\mathrm{Sr}$ and $\mathrm{Sm}-\mathrm{Nd}$ systematics can serve to identify the provenance of different tektites.

\section{REFERENCES}

BAKER G. (1968) Micro-forms of hay-silica glass and of volcanic glass. Mineral. Mag. 36, 1012-1023.

BALDwIN R. B. (1981) Tektites: Size estimates of their source craters and implications for their origin. Icarus 45, 554-563.

BARNeS V. E. (1940) Contributions to geology, 1939, part 2, North American tektites. Univ. Texas Publ. 3945, 477-583.

Bennett V. C. and DePaolo D. J. (1987) Proterozoic crustal history of the western United States as determined by neodymium isotopic mapping. Bull. Geol. Soc. Am. 99, 674-685.

Berggren W. A., Kent D. V. and Flynn J. J. (1985) Paleogene geochronology and chronostratigraphy. In Geochronology and the Geological Record (ed. N. J. Snelling), pp. 141-195. Geol. Soc. London Spec. Paper.

Bohor B. F., Betterton W. J. AND Foord E. E. (1988) Coesite, glass, and shocked quarts at DSDP site 612: Evidence for nearby impact in the Late Eocene (abstract). Lunar Planet. Sci. 19, 114-115.

BOTTOMLEY AND YORK (1988) Age measurement of the submarine Montagnais impact crater. Geophys. Res. Lett. 15, 1409-1412.

BOTTOMLEY AND YORK (1989) The dating of impact melt rocks using the ${ }^{40} \mathrm{Ar} /{ }^{39} \mathrm{Ar}$ method (abstract). Lunar Planet. Sci. 20, 101-102. 
Chalmers R. O., Henderson E. P. and Mason B. (1976) Occurrence, distribution, and age of Australian tektites. Smithson. Contrib. Earth Sci. 17, 1-46.

Cuttitta F., Clarke R. S., Jr., Carron M. K. and Annell C. S. (1967) Martha's Vineyard and selected Georgia tektites: New chemical data. J. Geophys. Res. 72, 1343-1349.

DASCH E. J. (1969) Strontium isotopes in weathering profiles, deepsea sediments, and sedimentary rocks. Geochim. Cosmochim. Acta 33, $1521-1552$.

D'Hondt S. L., Keller G. and Stallard R. (1987) Major element compositional variation within and between different late Eocene microtektite strewnfields. Meteoritics 22, 61-79.

DieTz R. S. (1977) Elgygytgyn crater, Siberia: Probable source of Australasian tektite field (and bediasites from Popigai). Meteoritics 12, $145-157$.

Donnelly T. W. and Chao E. C. T. (1973) Microtektites of late Eocene age from the eastern Caribbean Sea. Initial Repts. Deep Sea Drilling Project 15, 1031-1037.

FleisCHER R. L. AND PRICE P. B. (1964) Fission-track evidence for the simultaneous origin of tektites and other natural glasses. Geochim. Cosmochim. Acta 28, 755-760.

Garlick G. D., Naeser C. W. and O'Neil J. R. (1971) A Cuban tektite. Geochim. Cosmochim. Acta 35, 731-734.

GLASS B. P. (1984) Multiple microtektite horizons in upper Eocene marine sediments? Science 224, 309.

Glass B. P. (1987) Clinopyroxene-bearing spherules in the North American tektite layer from DSDP site 612 drilled on the continental slope off New Jersey (abstract). Meteoritics 22, 388-389.

GLass B. P. (1988) Montagnais impact crater: Possible source of the North American tektite strewn field (abstract). Lunar Planet. Sci. 19, 391-392.

Glass B. P. AND Burns C. A. (1987) Late Eocene crystal-bearing spherules: Two layers or one? Meteoritics 22, 265-279.

Glass B. P., Hall C. M. AND YoRK D. (1986a) ${ }^{40} \mathrm{Ar} /{ }^{39} \mathrm{Ar}$ laser-probe dating of North American tektite fragments from Barbados and the age of the Eocene-Oligocene boundary. Chem. Geol. (Isotope Geosci.) 59, 181-186.

GLass B. P. AND John C. (1974) Clinopyroxene-bearing glass spherules associated with North American microtektites. Geology 2, 599-602.

Glass B. P., Muenov D. W. ANd Aggrey K. E. (1986b) Further evidence for the impact origin of tektites (abstract). Meteoritics 21, 369-370.

Glass B. P and Zwart M. J. (1979) North American microtektites in Deep Sea Drilling Project cores from the Caribbean Sea and Gulf of Mexico. Bull. Geol. Soc. Am. 90, 595-602.

GoHN G. S. (1988) Late Mesozoic and early Cenozoic geology of the Atlantic coastal plan: North Carolina to Florida. In The Geology of North America, The Atlantic Continental Margin: U.S. (eds. R. E. Sheridan and J. A. Grow), pp. 107-130. Geological Society of America, Boulder.

Goldstein S. J. And Jacobsen S. B. (1988) The Nd and Sr isotopic systematics of river water suspended material: Implications for crustal evolution. Earth Planet. Sci. Lett. 87, 249-265.

Graup G., Horn P., Köhler H. AND Müller-Sohnius D. (1981) Source material for Moldavites and Bentonites. Naturwissenschaften 68, 616-617.

Grieve R. A. F. (1987) Terrestrial impact structures. Ann. Rev. Earth Planet. Sci. 15, 245-270.

Horn P., Müller-Sohnius D., Köhler H. ANd Graup G. (1985) Rb$\mathrm{Sr}$ systematics of rocks related to the Ries Crater, Germany. Earth Planet. Sci. Lett. 75, 384-392.

JANSA L. F. AND PE-PIPER G. (1987) Identification of an underwater extraterrestrial impact crater. Nature 327, 612-614.

Kaye C. A., Schnetzler C. C. and Chase J. N. (1961) Tektite from Martha's Vineyard, Massachusetts. Bull. Geol. Soc. Am. 72, 339-340.

KELLER G. AND D'Hondt S. (1988) Late Eocene crystal-bearing spherules: Two layers or one? A reply to the critique by B. P. Glass and C. A. Burns. Meteoritics 23, 167-169.

Keller G., D'Hondt S. AND Vallier T. L. (1983) Multiple microtektite horizons in upper Eocene marine sediments: No evidence for mass extinctions. Science 221, 150-152.

Keller G., D'Hondt S. AND Vallier T. L. (1984) Multiple microtektite horizons in upper Eocene marine sediments? Science 224, 309310 .
Keller G., D'Hondt S. L., Orth C. J., Gilmore J. S., Oliver P. Q., Shoemaker E. M. and Molina E. (1987) Late Eocene impact microspherules: Stratigraphy, age and geochemistry. Meteoritics 22, 2560.

KIEFFER S. W. (1977) Impact conditions required for formation of melt by jetting in silicates. In Impact and Explosion Cratering (eds. D. J. Roddy, R. O. Pepin and R. B. Merrill), pp. 751-769. Pergamon, New York.

Koeberl C. AND Glass B. P. (1988) Chemical composition of North American microtektites and tektite fragments from Barbados and DSDP Site 612 on the continental slope off New Jersey. Earth Planet. Sci. Lett. 87, 286-292.

KrINOv E. L. (1966) Giant meteorites. Pergamon, 397 pp.

Mak E. K., York D., Grieve R. A. F. and Dence M. R. (1976) The age of the Mistastin Lake crater, Labrador, Canada. Earth Planet. Sci. Lett. 31, 345-357.

Masaitis V. L., Danilin A. N., Mashchak M. S., RaYkhlin A. I., Selivanovskaya T. V. And Shadenkov Ye. M. (1980) Geologiya Astroblem. Nedra, Leningrad, $231 \mathrm{pp}$.

McCulloch M. T. ANd Wasserburg G. J. (1978) Sm-Nd and RbSr chronology of continental crust formation. Science 200, 10031011.

McLennan S. M., Nance W. B. And Taylor S. R. (1980) Rare earth element-thorium correlations in sedimentary rocks, and the composition of the continental crust. Geochim. Cosmochim. Acta 44, 18331839.

Melosh H. J. (1981) Atmospheric breakup of terrestrial impactors. In Multi-Ring Basins (eds. P. H. Schultz and R. B. Merrill), pp. 2936. Pergamon, New York.

Miller K. G. ANd HaRT M. B. (1987) Cenozoic planktonic foraminifers and hiatuses on the New Jersey slope and rise: Deep Sea Drilling Project Leg 95, Northwest Atlantic. Initial Repts. Deep Sea Drilling Project 95, 565-579.

Montanari A., Drake R., Bice D. M., Alvarez W., Curtis G. H., Turrin B. D. AND DePAolo D. J. (1985) Radiometric time scale for the upper Eocene and Oligocene based on $\mathrm{K} / \mathrm{Ar}$ and $\mathrm{Rb} / \mathrm{Sr}$ dating of volcanic biotites from the pelagic sequence of Gubbio, Italy. Geology 13, 596-599.

Ngo H. H., Wasserburg G. J. and Glass B. P. (1985) Nd and $\mathrm{Sr}$ isotopic compositions of tektite material from Barbados and their relationship to North American tektites. Geochim. Cosmochim. Acta 49, 1479-1485.

Olsson R. K., Gibson T. G., Hansen H. J. and Owens J. P. (1988) Geology of the northern Atlantic coastal plain: Long Island to Virginia. In The Geology of North America, The Atlantic Continental Margin: U.S. (eds. R. E. Sheridan and J. A. Grow), pp. 87-105. Geological Society of America, Boulder.

POAG C. W. AND Low D. (1987) Unconformable sequence boundaries at Deep Sea Drilling Project site 612, New Jersey transect: Their characteristics and stratigraphic significance. Initial Repts. Deep Sea Drilling Project 95, 453-498.

Pohl J., Stöfrler D., Gall H. and Ernstson K. (1977) The Ries impact crater. In Impact and Explosion Cratering (eds. D. J. Roddin, R. O. Pepin and R. B. Merrill), pp. 343-404. Pergamon, New York.

Papanastassiou D. A. and Wasserburg G. J. (1981) Microchrons: The ${ }^{87} \mathrm{Rb}^{87} \mathrm{Sr}$ dating of microscopic samples. Proc. Lunar Planet. Sci. 12B, 1027-1038.

Papanastassiou D. A., DePaolo D. J. and Wasserburg G. J. (1977) $\mathrm{Rb}-\mathrm{Sr}$ and $\mathrm{Sm}-\mathrm{Nd}$ chronology and genealogy of mare basalts from the Sea of Tranquility. Proc. Lunar Sci. Conf. 8th, 1639-1672.

REIFF W. (1977) The Steinheim Basin - an impact structure. In Impact and Explosion Cratering (eds. D. J. Roddin, R. O. Pepin, and R. B. Merrill), pp. 309-320. Pergamon, New York.

Sanfilippo A., Reidel W. R., Glass B. P. and Kyte F. T. (1985) Late Eocene microtektites and radiolarian extinctions on Barbados. Nature 314, 613-615.

Shaw H. F. AND Wasserburg G. J. (1982) Age and provenance of the target for tektites and possible impactites as inferred from SmNd and Rb-Sr systematics. Earth Planet. Sci. Lett. 60, 155-177.

Shaw H. F. AND Wasserburg G. J. (1984) Isotopic constraints on the origin of Appalachian mafic complexes. Am. J. Sci. 284, 319349.

Stecher O., Ngo H. H., Papanastassiou D. A., Wasserburg G. J. AND JANSA L. F. (1989) Rb-Sr and Sm-Nd signatures from the 
Montagnais and Popigai impact craters (abstract). Lunar Planet. Sci. 20, 1048-1049.

Storzer D. AND WAGNeR G. A. (1971) Fission-track ages of North American tektites. Earth Planet. Sci. Lett. 10, 434-444.

Storzer D. AND Wagner G. A. (1979) Fission-track dating of Elgygytgyn, Popigai and Zhamanshin impact craters: No sources for Australasian or North American tektites. Meteoritics 14, 541-542.

Storzer D., WAGNer G. A. AND KING E. A. (1973) Fission-track ages and stratigraphic occurrence of Georgia tektites. J. Geophys. Res. 78, 4915-4919.

TAYLOR F. C. AND DenCE M. R. (1969) A probable meteorite origin for Mistastin Lake, Labrador. Can. J. Earth Sci. 6, 39-45.

TAYLOR H. P. AND EPSTEIN S. (1969) Correlations between $\mathrm{O}^{18} / \mathrm{O}^{16}$ ratios and chemical compositions of tektites. J. Geophys. Res. 74, 6834-6844.
TAYLOR S. R. AND MCLennan S. M. (1981) The composition and evolution of the continental crust: Rare earth element evidence from sedimentary rocks. Phil. Trans. Roy. Soc. London A301, 381-398.

TheIN J. (1987) A tektite layer in Upper Eocene sediments of the New Jersey continental slope (site 612, leg 95). Initial Repts. Deep Sea Drilling Project 95, 565-579.

von Engelhardt W., Luft E., ARndt J., Schock H. AND WeiskirchNER W. (1987) Origin of moldavites. Geochim. Cosmochim. Acta 51, 1425-1443.

ZäHRINGER J. (1963) K-Ar measurements of tektites. In Radioactive Dating: Proceedings Symposium Athens, pp. 289-305. IAEA Int. At. Energy Agency, Vienna. 